\title{
Indonesian Bank's Efficiency Under Intermediation, Operating and Value Added Approach
}

\author{
Nurafni Eltivia \\ (Accounting Department, State Polytechnic of Malang, Indonesia)
}

\begin{abstract}
The aim of this research is to know how different approach can give different impact to Indonesian bank's efficiency. The efficiency of bank measured by non parametric analysis, using Data Envelopment Analysis. This research will employ three approach, Intermediation, Operating and Value Added to define the inputs-outputs used in Data Envelopment Analysis. There are 30 banks that used as samples in this research, consist of 4 government banks, 9 Go Public Banks, 11 Joint Venture Banks, and 6 Foreign Banks. The results show that using Value Added approach give highest score in efficiency. Based on the result, the Indonesian banks concern so far is how to increase the deposit, loans and the investments.
\end{abstract}

Keywords - bank efficiency, DEA, Intermediation Approach, Operating Approach, Value Added Approach

\section{Introduction}

Efficiency improvement in banking sector can be achieved by minimizing input, or otherwise maximizing output. Banking industry nowadays is in high competitive level with relatively similar type of products. This situation requires bank to improve its service quality in order to meet the customers' satisfaction. Service quality comprises product quality, cost and benefit of certain products, as well as how those products to be delivered to consumers. If both issues can be optimized, then the output will be optimized. High efficiency can be used as one of strategies to take a lead in the midst of the increasingly tight competition. When the efficiency can be achieved, bank will be able to implement its function well as intermediary institution. It becomes liquid and can distribute its fund. If the bank is not liquid, it can cause the decrease of customers' trust and its performance. On the contrary, if the bank is over liquid, bank will be burdened with the cost incurred from customers' deposit and the fund is not distributed well in which, in turn, this can degrade the bank's performance.

Efficiency is influenced by both input and output factor, banking industry involves multiple input and output. This research will find the efficiency of Indonesian bank that consist of foreign bank, government bank, and private bank. The efficiency score will measure by Data Envelopment Analysis, as the inputs and outputs will be seen based on thre approach, intermediation, operating and value added.

\section{LITERATURE REVIEW}

Efficiency concept relates to the comparison between the amount of input used and the amount of output generated. In this case, input is resource used in order to generate output. Meanwhile, output is result or yield of certain organization. Efficiency is one of performance parameter which is theoretically is one of performance measurements which serves as the basis of the whole organization performance. Efficiency is commonly use as one of performance tool measure in bank industry because it can provide an answer for various problems (Hadad et al, 2003). Research which was conducted by Farrel (1957) has given contribution in measuring efficiency and productivity in micro level. The research defined efficiency and productivity, and how to calculate benchmark and measure efficiency.

Farrel (1957) states that efficiency consists of two components, such as: 1) technical efficiency and 2) allocative efficiency. Technical efficiency reflects the ability of certain DMU to minimize the use of input in order to generate the given output. Meanwhile, allocative efficiency is ability of certain DMU to use inputs in optimal proportion based on the respective cost and production technology used. Both measurements will represent the measurement of total efficiency (Coelli, 1997). Efficiency ratio will generate a value between 0 and 1. Value 1 indicates that DMU is fully efficient. For example, one score efficiency is measured against cost frontier of $90 \%$, it means that the DMU can be reduced by $10 \%$ without changing the original output.

Afterwards, estimation on efficiency can be categorized based on assumption and technique used in composing efficient frontier. On one hand, parametric method estimate frontier line by using statistic method. On the other hand, non parametric method relies on linear programming in order to calculate relative linear segment on the frontier line. Parametric method determines the inefficiency rate based on the explicit functional both from the frontier itself and deviation of frontier standard. In contrast to parametric method, non parametric method does not formulate assumption both concerning frontier functional form and distribution assumption concerning efficiency. 
The selection of parametric and non parametric method on the composition of efficiency frontier will appear on the overall difference between observed inefficiency DMU and efficiency benchmark DMU. According to Fiorentino (2006), it happens because "parametric method use on estimation of the frontier, in turn, allow for random noise in the analysis, so that involves the estimation of a stochastic frontier. Non parametric methods, in turn allows random error in observed input-output combinations".

Determining input-output which are used to calculate efficiency is one of important phases either when using parametric method or non parametric method. There are several concepts which usually used in determining the relationship of input-output, the operating approach, the intermediation approach, and more recently, the revenue or (value added) approach. The operating approach (or income based approach) views banks as business units with the final objective of generating revenue from the total cost incurred for running the business (Leightner and Lovell, 1998).Under the intermediation approach the financial firms view as an intermediary between savers and borrowers and posits total loans and securities as outputs, whereas deposits along with labour and physical capital are defined as inputs. Accordingly, it defines banks' output as total revenue (interest and non-interest income) and inputs as the total expenses (interest and non-interest expenses). The value added approach in DEA is a new approach proposed by Drake et al (2006). This approach identifies the accounts on balance sheet categories as outputs that contribute to the bank value added. Under this approach, deposits and loans are viewed as outputs because these accounts responsible to create value added.

\section{Research Methodology}

There are 30 banks that employ in this research, consist of 4 government banks, 9 Go Public Banks, 11 Joint Venture Banks, and 6 Foreign Banks. The data will be taken from the financial report of each bank, time period is start from 2004 untul 2011. The financial report will obtain from the central bank official website. There are Data Envelopment Analysis will used to measure the efficiency score of each bank per year. Software that used to analyzed the efficiency score is Banxia Frontier Analyst $3^{\text {rd }}$ version, 2003.

The input and output define by three approach, intermediation, value added operating. Under the intermediation approach, we assume deposits (x2), labour (x3), and capital (x1) as inputs for producing loans (y1) and investments (y2). Under the value added approach, labour (x3), capital (x1), and interest expenses (x4) are used as inputs producing outputs like deposits (x2), loans (y1), and investments (y2). Under the operating approach, three types of inputs are considered namely, interest expenses (x4), labour (x3), and other operating expenses excluding employee expenses (x5). The relevant outputs are interest income (y3) and non-interest income (y4) emanating mostly from commission, exchange, brokerage, etc.

Table 1. Input- Output Used on Each Approach

\begin{tabular}{|l|l|l|}
\hline Approach & Input & Output \\
\hline Intermediation & Deposits, Labor, Capital & Loans, Investments \\
\hline Operating & $\begin{array}{l}\text { Interest Expense, Labor, Other } \\
\text { Expenses }\end{array}$ & $\begin{array}{l}\text { Interest Revenue, Non-Interest } \\
\text { Revenue }\end{array}$ \\
\hline Value Added & Labor, Capital, Interest Expense & Deposits, Loans, Investments \\
\hline
\end{tabular}

\section{Result}

The descriptive statistic is used to explain the result of efficiency score. Under intermediation approach, deployment efficiency score samples analyzed experiencing an upward trend in the first three years (2004 s / d 2006). On the other hand, during the 8-year period of the analysis of the number of banks located in a score of 1 or at intervals of 1 standard deviation (mean + standard deviation score samples samples) number of $49.58 \%$. Most of the scores of banks are inefficient value 0.695 , which is the average of the interval with a standard deviation score of efficiency. In the year 2011 is the year most banks are the most efficient sample compared to the previous year in terms of the intermediation approach. However, the year 2006 was actually the most efficient compared to others, because the average score of the highest efficiency and lowest standard deviation achieved this year. Most banks have efficiency score falls closest (at 0.772) close to one standard deviation.

The operation approach produce the worst efficiency score than the other two approaches. Interval difference between positive and negative difference between the average of the standard deviation indicate that many banks generate efficiency values close to 0 . In terms of value added approach, because the composition of the benchmark input-output comparator has changed, the proportion of the average score that quantified each other between bank efficiency scores. This is indicated by the difference in the average interval with a standard deviation, which means that many banks have efficiency values close to 1 (the value of efficiency has a great value with a small variance). This value added approach also yields higher efficiency values than the intermediation approach. 
Table 2. Efficiency of Indonesian Banks (Intermediation Approach)

\begin{tabular}{|c|c|c|c|c|c|c|c|c|c|}
\hline \multirow[t]{2}{*}{ Year } & \multirow{2}{*}{$\begin{array}{l}\sum_{\text {Banks }} \text { of } \\
\text { San }\end{array}$} & \multirow{2}{*}{$\begin{array}{l}\sum \text { of } \\
\text { Efficient } \\
\text { Banks }\end{array}$} & \multirow{2}{*}{$\begin{array}{l}\text { Average } \\
\text { of } \\
\text { Efficiency } \\
\text { (M) }\end{array}$} & \multirow{2}{*}{$\begin{array}{l}\text { Average of } \\
\text { Inefficiency } \\
{[(1-M) / M]}\end{array}$} & \multirow{2}{*}{$\begin{array}{l}\text { Standard } \\
\text { Deviation } \\
(\sigma)\end{array}$} & \multirow{2}{*}{$\begin{array}{l}\text { Mini- } \\
\text { mum }\end{array}$} & \multicolumn{2}{|c|}{ Interval } & \multirow{2}{*}{$\begin{array}{c}\% \\
\text { Efficient } \\
\text { Bank }\end{array}$} \\
\hline & & & & & & & $(\mathrm{M}-\sigma)$ & $\begin{array}{l}\text { (M+ } \\
\sigma)\end{array}$ & \\
\hline 2004 & 30 & 13 & 0.810 & 0.233 & 0.217 & 0.227 & 0.593 & 1.027 & 43,33 \\
\hline 2005 & 30 & 15 & 0.863 & 0.159 & 0.186 & 0.257 & 0.677 & 1.049 & 50 \\
\hline 2006 & 30 & 14 & 0.904 & 0.106 & 0.132 & 0.419 & 0.772 & 1.036 & 46,67 \\
\hline 2007 & 30 & 13 & 0.871 & 0.148 & 0.162 & 0.536 & 0.709 & 1.033 & 43,33 \\
\hline 2008 & 30 & 15 & 0.848 & 0.179 & 0.190 & 0.366 & 0.658 & 1.038 & 50 \\
\hline 2009 & 30 & 17 & 0.890 & 0.123 & 0.175 & 0.439 & 0.715 & 1.065 & 56,67 \\
\hline 2010 & 30 & 14 & 0.876 & 0.141 & 0.150 & 0.552 & 0.726 & 1.026 & 46,67 \\
\hline 2011 & 30 & 18 & 0.884 & 0.131 & 0.174 & 0.337 & 0.710 & 1.058 & 60 \\
\hline
\end{tabular}

Table 3. Efficiency of Indonesian Banks (Operating Approach)

\begin{tabular}{|c|c|c|c|c|c|c|c|c|c|}
\hline \multirow[t]{2}{*}{ Year } & \multirow{2}{*}{$\begin{array}{l}\text { of } \\
\text { Banks }\end{array}$} & \multirow{2}{*}{$\begin{array}{l}\sum \text { of } \\
\text { Efficient } \\
\text { Banks }\end{array}$} & \multirow{2}{*}{$\begin{array}{l}\text { Average } \\
\text { of } \\
\text { Efficiency } \\
\text { (M) }\end{array}$} & \multirow{2}{*}{$\begin{array}{l}\text { Average of } \\
\text { Inefficiency } \\
{[(1-\mathrm{M}) / \mathrm{M}]}\end{array}$} & \multirow{2}{*}{$\begin{array}{l}\text { Standard } \\
\text { Deviation } \\
(\sigma)\end{array}$} & \multirow[t]{2}{*}{ Minimum } & \multicolumn{2}{|c|}{ Interval } & \multirow{2}{*}{\begin{tabular}{l}
\multicolumn{1}{c}{$\%$} \\
Efficient \\
Bank
\end{tabular}} \\
\hline & & & & & & & $\begin{array}{l}\text { (M- } \\
\sigma)\end{array}$ & $\begin{array}{l}(\mathrm{M}+ \\
\sigma)\end{array}$ & \\
\hline 2004 & 30 & 10 & 0.765 & 0.306 & 0.213 & 0.370 & 0.552 & 0.978 & 33,33 \\
\hline 2005 & 30 & 14 & 0.752 & 0.329 & 0.284 & 0.226 & 0.468 & 1.036 & 46,67 \\
\hline 2006 & 30 & 10 & 0.707 & 0.414 & 0.289 & 0.195 & 0.418 & 0.996 & 33,33 \\
\hline 2007 & 30 & 14 & 0.789 & 0.268 & 0.240 & 0.308 & 0.549 & 1.029 & 46,67 \\
\hline 2008 & 30 & 14 & 0.767 & 0.303 & 0.291 & 0.278 & 0.476 & 1.058 & 46,67 \\
\hline 2009 & 30 & 11 & 0.766 & 0.306 & 0.249 & 0.347 & 0.517 & 1.015 & 36,67 \\
\hline 2010 & 30 & 13 & 0.809 & 0.236 & 0.232 & 0.346 & 0.577 & 1.041 & 43,33 \\
\hline 2011 & 30 & 15 & 0.816 & 0.225 & 0.244 & 0.345 & 0.572 & 1.060 & 50 \\
\hline
\end{tabular}

Table 4. Efficiency of Indonesian Banks (Value Added Approach)

\begin{tabular}{|c|c|c|c|c|c|c|c|c|c|}
\hline \multirow[t]{2}{*}{ Year } & \multirow{2}{*}{$\begin{array}{l}\sum \text { of } \\
\text { Banks }\end{array}$} & \multirow{2}{*}{$\begin{array}{l}\sum \text { of } \\
\text { Efficient } \\
\text { Banks }\end{array}$} & \multirow{2}{*}{$\begin{array}{l}\text { Average } \\
\text { of } \\
\text { Efficiency } \\
\text { (M) }\end{array}$} & \multirow{2}{*}{$\begin{array}{l}\text { Average of } \\
\text { Inefficiency } \\
{[(1-M) / M]}\end{array}$} & \multirow{2}{*}{$\begin{array}{l}\text { Standard } \\
\text { Deviation } \\
(\sigma)\end{array}$} & \multirow[t]{2}{*}{ Minimum } & \multicolumn{2}{|c|}{ Interval } & \multirow{2}{*}{\begin{tabular}{l}
\multicolumn{1}{c}{$\%$} \\
Efficient \\
Bank
\end{tabular}} \\
\hline & & & & & & & $\begin{array}{l}\text { (M- } \\
\sigma)\end{array}$ & $\begin{array}{l}\text { (M+ } \\
\sigma)\end{array}$ & \\
\hline 2004 & 30 & 17 & 0,933 & 0,071 & 0,089 & 0,745 & 0,844 & 1,022 & 56,67 \\
\hline 2005 & 30 & 20 & 0,93 & 0,075 & 0,119 & 0,586 & 0,811 & 1,049 & 66,67 \\
\hline 2006 & 30 & 19 & 0,947 & 0,055 & 0,093 & 0,625 & 0,853 & 1,040 & 63,33 \\
\hline 2007 & 30 & 16 & 0,904 & 0,106 & 0,151 & 0,475 & 0,752 & 1,055 & 53,33 \\
\hline 2008 & 30 & 17 & 0,897 & 0,115 & 0,142 & 0,498 & 0,755 & 1,039 & 56,67 \\
\hline 2009 & 30 & 16 & 0,869 & 0,151 & 0,181 & 0,450 & 0,688 & 1,049 & 53,33 \\
\hline 2010 & 30 & 13 & 0,876 & 0,141 & 0,164 & 0,273 & 0,712 & 1,040 & 43,33 \\
\hline 2011 & 30 & 16 & 0,867 & 0,153 & 0,177 & 0,475 & 0,690 & 1,045 & 53,33 \\
\hline
\end{tabular}

\section{CONCLUSION}

Bank efficiency in Indonesia still need a big concern, since the efficiency score showed that most of the banks are not efficient. The efficiency score measured by DEA using the inputs and outputs of the banks. The best score of efficiency created by value added approach. This approach employs labor, capital ad interest expense as inputs and deposits loans and investments as the outputs. Based on the result, the Indonesian banks concern so far is how to increase the deposit, loans and the investments. Under the operating approach Indonesian banks fail to reach good performance on collecting interest revenue and non interest revenue, because the result shows the worst score. In the next time, Indonesian Banks must keep on balancing both the performance of the balance sheet and profit loss report, so the performance will raising comprehensively.

\section{REFERENCES}

[1] Hadad, Muliaman D., Santoso, W., dan Mardanugraha, E., Illyas, D. 2003. Analisis Efisiensi Industri Perbankan Indonesia: Penggunaan Metode Non Parametrik Data Envelopment Analysis. Buletin Ekonomi Moneter Perbankan.

[2] Farrel, M.J. The measurement of productive efficiency, Journal of the Royal Statistical Society, 1998, 253-290.

[3] Coelli T, D S Prasada Rao, and G E Batese, An introduction to efficiency and productivity analysis (Boston: Springer, 1997).

[4] Fiorentino E, Karmann A, and Koetter M, The cost efficiency of German banks: a comparison of SFA and DEA, Discussion Paper Series 2: Banking and Financial Studies, 10,2006, Deutsche Bundesbank.

[5] Leightner J E, and Lovell C A K, The impact of financial liberalization on the performance of Thai bank, J. Econ. Business 50, 1998, $115-131$

[6] Drake L, Hall M J B, Simper R., The impact of macroeconomic and regulatory factors on bank efficiency: a non-parametric analysis of Hong Kong's banking system, J. Bank. Finan. 30 (5), 2006,1443-1466. 